\title{
Radiation Hazards Indices of Silhouette Plants in Spring and Summer Seasons
}

\author{
Athraa Naji Jameel ${ }^{1}$, Nada Farhan Kadhim ${ }^{2, ~ *, ~ A b d u l w a h a b ~ R i d h a ~}{ }^{2,3}$ \\ ${ }^{1}$ Department of Physics, College of Education, Mustansiriyah University, Baghdad, Iraq \\ ${ }^{2}$ Department of Physics, College of Science, Mustansiriyah University, Baghdad, Iraq \\ ${ }^{3}$ Department of Science, Rustaq College of Education, Rustaq, Oman
}

Email address:

dr.nada@uomustansiryah.edu.iq (N. F. Kadhim)

${ }^{*}$ Corresponding author

\section{To cite this article:}

Athraa Naji Jameel, Nada Farhan Kadhim, Abdulwahab Ridha. Radiation Hazards Indices of Silhouette Plants in Spring and Summer Seasons. Plant. Vol. 7, No. 3, 2019, pp. 25-32. doi: 10.11648/j.plant.20190703.11

Received: July 21, 2019; Accepted: August 13,2019; Published: August 26, 2019

\begin{abstract}
The radiation hazards indices of common silhouette plants used in homes decoration were studied at two seasons; spring and summer. Twelve species of silhouette plants were collected from nurseries in Baghdad, six of them were collected in spring season others in summer season, each group were positioned in the laboratory at normal conditions. The measurements were carried out using $\mathrm{NaI}(\mathrm{Tl})$ gamma-ray spectrometry. Results shown a little difference between the mean specific activities of the radionuclides, they were $161.2 \pm 11.8,11.2 \pm 1.2 \mathrm{~Bq} / \mathrm{kg}$, and $5.8 \pm 0.5 \mathrm{~Bq} / \mathrm{kg}$ in spring season plants, $159.5 \pm 21.1,5.4 \pm 0.8 \mathrm{~Bq} / \mathrm{kg}$, and $6.4 \pm 0.4$ in summer season plants for $\mathrm{K}-40, \mathrm{Bi}-214$, and $\mathrm{Tl}-208$ respectively. According to these results the mean radiation hazard indices (The radium equivalent activity, absorbed dose rate, annual effective dose equivalent, external hazard indices, annual gonadal dose and excess lifetime cancer risk) were also convergent to each other in plant samples of both groups. The highest specific activities were appeared in Dareseny plant $197.11 \mathrm{~Bq} / \mathrm{kg}, 15.94 \mathrm{~Bq} / \mathrm{kg}$, and 7.8 $\mathrm{Bq} / \mathrm{kg}$ for K-40, Bi-214, and Tl-208 respectively. While in summer season the $\mathrm{K}-40(265.9 \mathrm{~Bq} / \mathrm{Kg})$ and $\mathrm{Bi}-214(8.6 \mathrm{~Bq} / \mathrm{Kg})$ were higher in sygonium, and Tl-208 is higher in Ficus Elatic $(9.2 \mathrm{~Bq} / \mathrm{Kg})$. All results are within the recommended values.
\end{abstract}

Keywords: Hazard Indices, Nai (Tl) Detector, Silhouette Plants, Specific Activity, Radium Equivalent Activity

\section{Introduction}

Human beings are exposed to background radiation that stems both from natural and man-made sources $[1,2]$. Natural background radiation, which is equivalent to $2.4 \mathrm{mSv}$ per person, Radon occurs widely in the environment, especially in rocks, soil, building materials and water [3, 4]. Primordial radionuclides of the decay series U-238 and Th232 exist naturally in the earth's crust [5]. These radionuclides enter the soil through the weathering of the earth crust [6]. Concentrations of U-238 and Th-232 in soil (one of the main factors affecting plant uptake of the radionuclides) differ significantly depending on the soil type, parent rocks, climate, relief, vegetation season and many other factors $[7,8]$. These radioactive elements find their way into plants by direct contact with atmosphere containing radionuclide, or by absorption of soluble radionuclide from soil-water to root uptake and re-suspended of radionuclide from soil. The radionuclide deposited directly with plant is either by dry deposition such as wind or by wet deposition such as rain. Meanwhile, the availability of radionuclide in soil and the uptake potential of each radioactive element are the main factors controlling the rate of uptake radionuclide from soil to plant $[9,10]$.

Plants acquire these radionuclides via their roots or leaves, and animals acquire them through consumption of plants, phosphate-based mineral food supplements and soils [11, 12]. Doses from radionuclides of natural origin in terrestrial foodstuffs are currently much higher than those from artificial radionuclides [13]. Radionuclide uptake of plants depends upon different factors such as soil type, texture, $\mathrm{pH}$, conductivity, and carbonate and sulphite contents [14]. The entry of trace contaminants, which are present in the terrestrial environment, into human food chains is controlled in the long term by their uptake by plant roots [15]. It was 
found that the tobacco plant contains leaves with leaves to help increase the adsorption of radon, tobacco leaves; it contains Sticky hair like structures on both sides of tobacco leave [16].

The aim of this study is to determine the activity concentration, and radiological risk of radionuclide Ra-226,232 and K-40 in different silhouette plant samples.

\section{Materials and Methods}

\subsection{Samples Collection}

Two groups of different species of silhouette plants are collected from various nurseries located in Baghdad. Each group is consists of six samples; first group includes plant samples collected in spring season at $8 / 5 / 2018$ as in figure 1 , other group consists of plants collected in summer season at $24 / 6 / 2018$ as in figure 2. Both groups were placed in the laboratory for 30 days in order to subject to the same natural laboratory conditions. The samples prepared by cutting, dried with oven at $80^{\circ} \mathrm{C}$ for $2 \mathrm{~h}$, crushed to fine powder, sieved through $630 \mu \mathrm{m}$ sieve to be homogenizes in size, stored in sealed in Marnille beaker, and left for four weeks to reach the secular equilibrium before they examined by the spectroscopy.

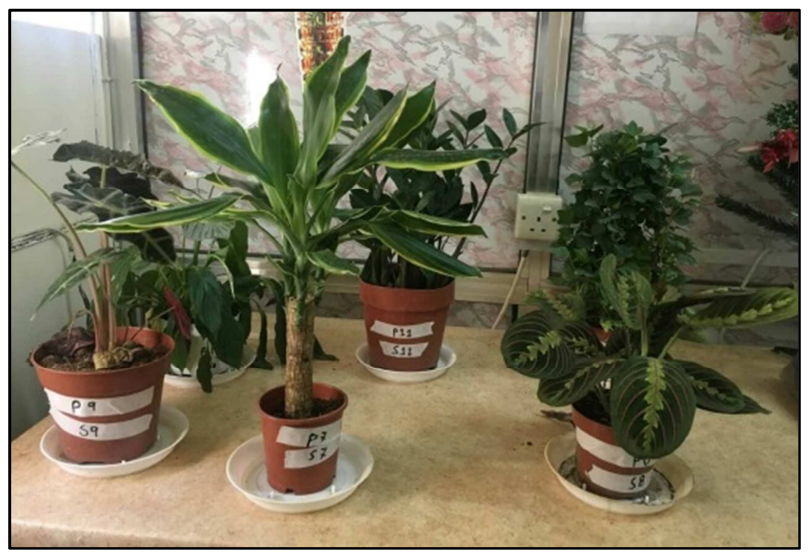

Figure 1. The silhouette Plants collected in spring season.

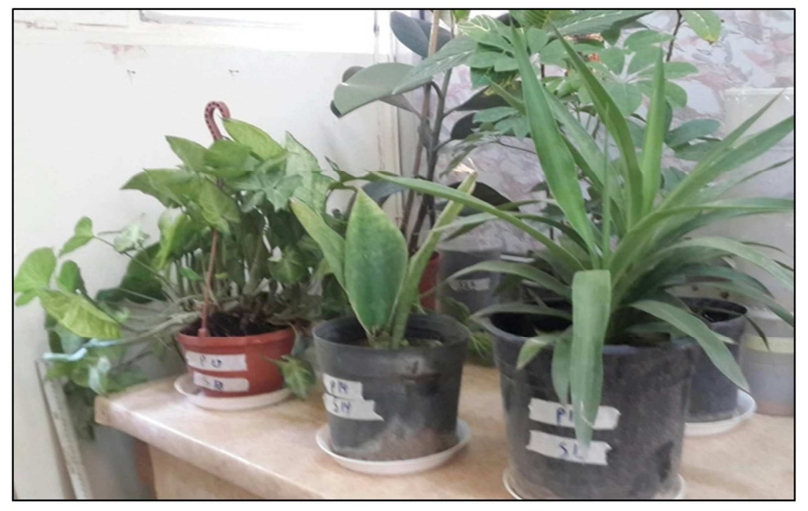

Figure 2. The silhouette Plants collected in summer season.

\subsection{NaI (Tl) Spectroscopy}

A scintillation detector $\mathrm{NaI}(\mathrm{Tl})$ gamma spectroscopy ofa

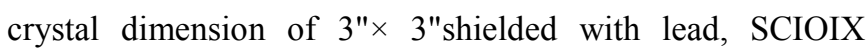
model 51S51, Germany origin have been used to perform this study. The system has a digital multichannel analyzer (bright multichannel SPEC model bMCA) of 4096 channels and $695 \mathrm{~V}$ operation voltage. The time of examination used were $24 \mathrm{hr}(86400 \mathrm{~s})[17,18]$.

\subsection{Specific Activity Calculations}

The activity concentrations of the plant measured by gamma spectrometry were calculated using the following relation $[19,20]$ :

$$
A(t)=\frac{N}{\varepsilon\left(E_{\gamma}\right) \times I\left(E_{\gamma}\right) \times m \times t} \times 100
$$

Where $\mathrm{N}$ is the net peak area under the specific peak, $\mathrm{t}$ is the time of measurement in second, I (E $\gamma)$ is the abundance of energy, $\varepsilon(E \gamma)$ is the detection efficiency at energy $E \gamma$, and $\mathrm{m}$ is the mass of the measured sample in $\mathrm{kg}$.

\subsection{Radiological Hazards Assessment}

\subsubsection{Radium Equivalent Activity}

Radium equivalent activity $\left(\mathrm{Ra}_{\mathrm{eq}}\right)$ is used to ensure the uniformity in the distribution of natural radionuclides ${ }^{226} \mathrm{Ra}$, ${ }^{232} \mathrm{Th}$, and ${ }^{40} \mathrm{~K}$ and is given by $[21,22]$ :

$$
\mathrm{Ra}_{\mathrm{eq}}(\mathrm{Bq} / \mathrm{kg})=\mathrm{A}_{\mathrm{Ra}}+1.43 \mathrm{ATh}+0.077 \mathrm{AK}
$$

Where $A_{R a}, A_{T h}$, and $A K$ are the specific activities of 226Ra, 232Th, and 40K respectively.

\subsubsection{External Hazard Index $\left(H_{e x}\right)$, Gamma Index $\left(I_{y}\right)$ and Alpha Index $\left(I_{\alpha}\right)$}

External hazard Index is reflecting the external radiation that the samples were exposed, it's defined by $[23,24]$ as:

$$
\mathrm{Hex}=\mathrm{A}_{\mathrm{Ra}} / 370+\mathrm{A}_{\mathrm{Th}} / 259+\mathrm{AK} / 4810 \leq 1
$$

The gamma index and Alpha index was calculated by using the following equation $[25,26]$ :

$$
\begin{gathered}
I_{y}=\frac{A_{R a}}{300}+\frac{A_{T h}}{200}+\frac{A_{K}}{3000} \leq 1 \\
\mathrm{I} \alpha=\mathrm{ARa} / 200 \leq 1
\end{gathered}
$$

\subsubsection{Absorbed Dose Rate $\left(D_{\gamma}\right)$, Annual Effective Dose Equivalent (AEDE)}

The absorbed dose rate in air due to gamma radiations in outdoor air at $1 \mathrm{~m}$ above the ground surface was calculated as follow [27]:

$$
\mathrm{D}_{\gamma}(\mathrm{nGy} / \mathrm{h})=0.462 \mathrm{~A}_{\mathrm{Ra}}+0.621 \mathrm{~A}_{\mathrm{Th}}+0.0417 \mathrm{~A}_{\mathrm{K}}
$$

The annual effective dose rate was calculated by the following equation [28]:

$$
\mathrm{AED}_{\text {in }}(\mathrm{mSv} / \mathrm{y})=\mathrm{D}_{\mathrm{y}} \times 10^{-6} \times 8760 \mathrm{~h} / \mathrm{y} \times 0.80 \times 0.7 \mathrm{~Sv} / \mathrm{Gy}(7)
$$

\subsubsection{Annual Gonadal Dose Equivalent (AGDE)}

The annual gonadal dose equivalent applied on endocrine according to the concentrations of ${ }^{226} \mathrm{Ra},{ }^{232} \mathrm{Th}$, and ${ }^{40} \mathrm{~K}$ was 
calculated by [29]:

$$
\operatorname{AGDE}(\mathrm{mSv} . \mathrm{y}-1)=(3.09 \mathrm{ARa}+4.18 \mathrm{ATh}+0.314 \mathrm{AK}) \times 10^{-3}
$$

\subsubsection{Excess lifetime Cancer Risk (ELCR) of Human}

The Excess lifetime cancer risk (ELCR) was calculated by:

$$
\mathrm{ELCR}=\mathrm{AEDE} \times \mathrm{DL} \times \mathrm{RF}
$$

is the risk factor $0.05 \mathrm{~Sv}^{-1}[30]$.

\section{Results and Discussion}

The mean specific activates of the radionuclide's ${ }^{226} \mathrm{Ra}$, ${ }^{232} \mathrm{Th}$, and ${ }^{40} \mathrm{~K}$ that have been detected in the two group are shown in table 1 .

Where, AEDE is the annual effective dose equivalent, DL is the average life duration (estimated to be 70years), and RF

\begin{tabular}{|c|c|c|c|c|c|c|c|c|c|}
\hline \multicolumn{10}{|c|}{ Specific activity of the Plants $(\mathrm{Bq} / \mathrm{Kg})$} \\
\hline \multicolumn{5}{|c|}{ spring season } & \multicolumn{5}{|c|}{ summer season } \\
\hline Code & plant & K-40 & Bi-214 & Tl-208 & Code & plant & K-40 & Bi-214 & Tl-208 \\
\hline P1 & Daresenya & 197.11 & 15.94 & 7.8 & P7 & Syngonium & 265.9 & 7.2 & 8.6 \\
\hline $\mathrm{P} 2$ & Marnta & 172.91 & 10.75 & 4.69 & P8 & Sanseveria & 108.5 & 5 & 5.2 \\
\hline P3 & Alocasia & 144.94 & 14.75 & 5.98 & P9 & Yucca elephant & 119.5 & 3.4 & 6.4 \\
\hline P4 & Spaty & 135.5 & 9.7 & 6.3 & P10 & Ficus Elastic & 172.3 & 9.2 & 6.3 \\
\hline P5 & Zamya & 122 & 8.66 & 6.84 & P11 & Amazonia & 133.9 & 3.1 & 7.1 \\
\hline \multicolumn{2}{|l|}{ Max. } & 197.11 & 15.94 & 11.59 & Max. & & 265.9 & 9.2 & 8.6 \\
\hline \multicolumn{2}{|l|}{ Min. } & 122 & 7.45 & 3.67 & Min. & & 108.5 & 3.1 & 5.2 \\
\hline \multicolumn{2}{|c|}{ Mean \pm S.E } & $161.2 \pm 11.8$ & $11.2 \pm 1.2$ & $5.8 \pm 0.5$ & Mean \pm & & $159.5 \pm 21.1$ & $5.4 \pm 0.8$ & $6.4 \pm 0.4$ \\
\hline \multicolumn{2}{|c|}{ W. A. [UNSCEAR 2000] } & 400 & 20 & 15 & \multicolumn{2}{|c|}{ W. A. [UNSCEAR 2000] } & 400 & 20 & 15 \\
\hline
\end{tabular}

Table 1. Specific activity concentrations of silhouette plants.

Note: W. A. =Worldwide Average

It is observed that the mean specific activates of first group of plants samples collected in spring season are higher than the mean values of the second group of plants samples collected in summer season. As they were $161.2 \pm 11.8 \mathrm{~Bq} / \mathrm{kg}$, and $11.2 \pm 2.3 \mathrm{~Bq} / \mathrm{kg}$ at first group, and $159.5 \pm 21.1 \mathrm{~Bq} / \mathrm{kg}$, and $5.4 \pm 0.8 \mathrm{~Bq} / \mathrm{kg}$ at second group for ${ }^{40} \mathrm{~K}$ and ${ }^{214}$ Birespectively. Exceptfor Tl-208at which mean specific activates of first group $5.8 \pm 5 \mathrm{~Bq} / \mathrm{kg}$ was lower than the mean specific activates of the second group $6.4 \pm 0.4$. The overall mean specific activates is shown in figure 3 .

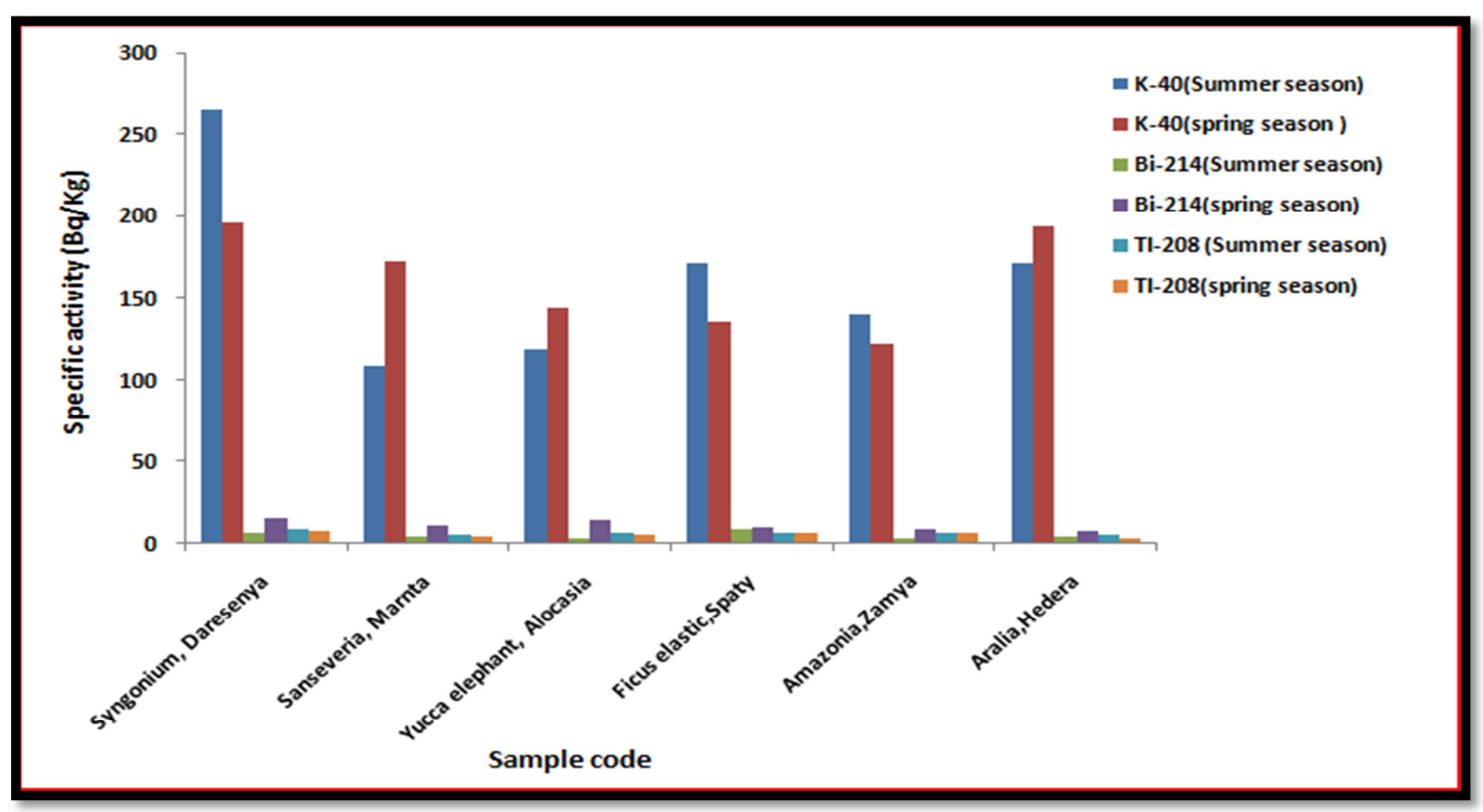

Figure 3. The specific activities of ${ }^{40} \mathrm{~K},{ }^{214} \mathrm{Bi}$, and ${ }^{208} \mathrm{Tl}$ of two seasons.

The results listed in tables 2, 3 shown the radiometric parameters' of the silhouette plants for spring and summer seasons. 
Table 2. The radiometric parameters of spring season Plants.

\begin{tabular}{|c|c|c|c|c|c|c|c|c|c|}
\hline No. & Code & $\operatorname{Raq}(\mathrm{Bq} / \mathrm{Kg})$ & Hex & $\mathbf{I} \gamma$ & $\mathbf{I a}$ & $D \gamma(\mathrm{nGy} / \mathrm{h})$ & Eff (dose (mSv/y) & AGDE $[\mathrm{mSv} / \mathrm{y})$ & ELCR \\
\hline 1 & P1 & 42.28 & 0.11 & 0.15 & 0.08 & 20.42 & 0.1 & 0.14 & 0.35 \\
\hline 2 & $\mathrm{P} 2$ & 30.77 & 0.08 & 0.11 & 0.05 & 15 & 0.074 & 0.10 & 0.25 \\
\hline 3 & P3 & 34.46 & 0.09 & 0.12 & 0.07 & 16.5 & 0.081 & 0.116 & 0.28 \\
\hline 4 & P4 & 29.14 & 0.07 & 0.109 & 0.049 & 14 & 0.069 & 0.099 & 0.24 \\
\hline 5 & P5 & 27.84 & 0.075 & 0.104 & 0.043 & 13.3 & 0.065 & 0.094 & 0.22 \\
\hline 6 & P6 & 27.7 & 0.07 & 0.10 & 0.037 & 13 & 0.06 & 0.1 & 0.20 \\
\hline \multicolumn{2}{|c|}{ Max. } & 42.28 & 0.11 & 0.15 & 0.08 & 20.42 & 0.1 & 0.14 & 0.35 \\
\hline \multicolumn{2}{|c|}{ Mean \pm S.E } & $32 \pm 2.0$ & $0.09 \pm 0.008$ & $0.11 \pm 0.006$ & $0.05 \pm 0.006$ & $15.3 \pm 1$ & $0.07 \pm 0.002$ & $0.1 \pm 0.006$ & $0.25 \pm 0.01$ \\
\hline \multicolumn{2}{|c|}{ Global limit } & $\begin{array}{l}370 \\
2000][10]\end{array}$ & $\leq 1$ & $\leq 1$ & $\leq 1$ & 55 & 1 & 0.3 & $\begin{array}{l}0.95[\text { ICRP.,2012] } \\
{[31]}\end{array}$ \\
\hline
\end{tabular}

Table 3. The radiometric parameters of summer season Plants.

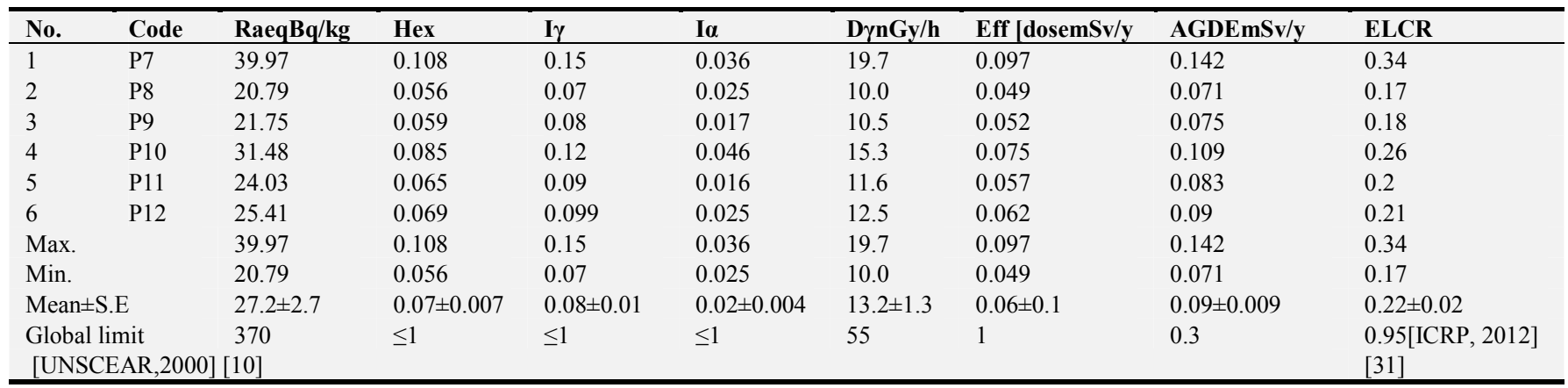

The mean radium equivalent activity of the plants at spring season was $32 \pm 2 \mathrm{~Bq} / \mathrm{kg}$ which is higher than the mean values of the plants at summer season $27.2 \pm 2.7 \mathrm{~Bq} / \mathrm{kg}$. The radium equivalent for two groups of silhouette plants is shown in figure 4 .

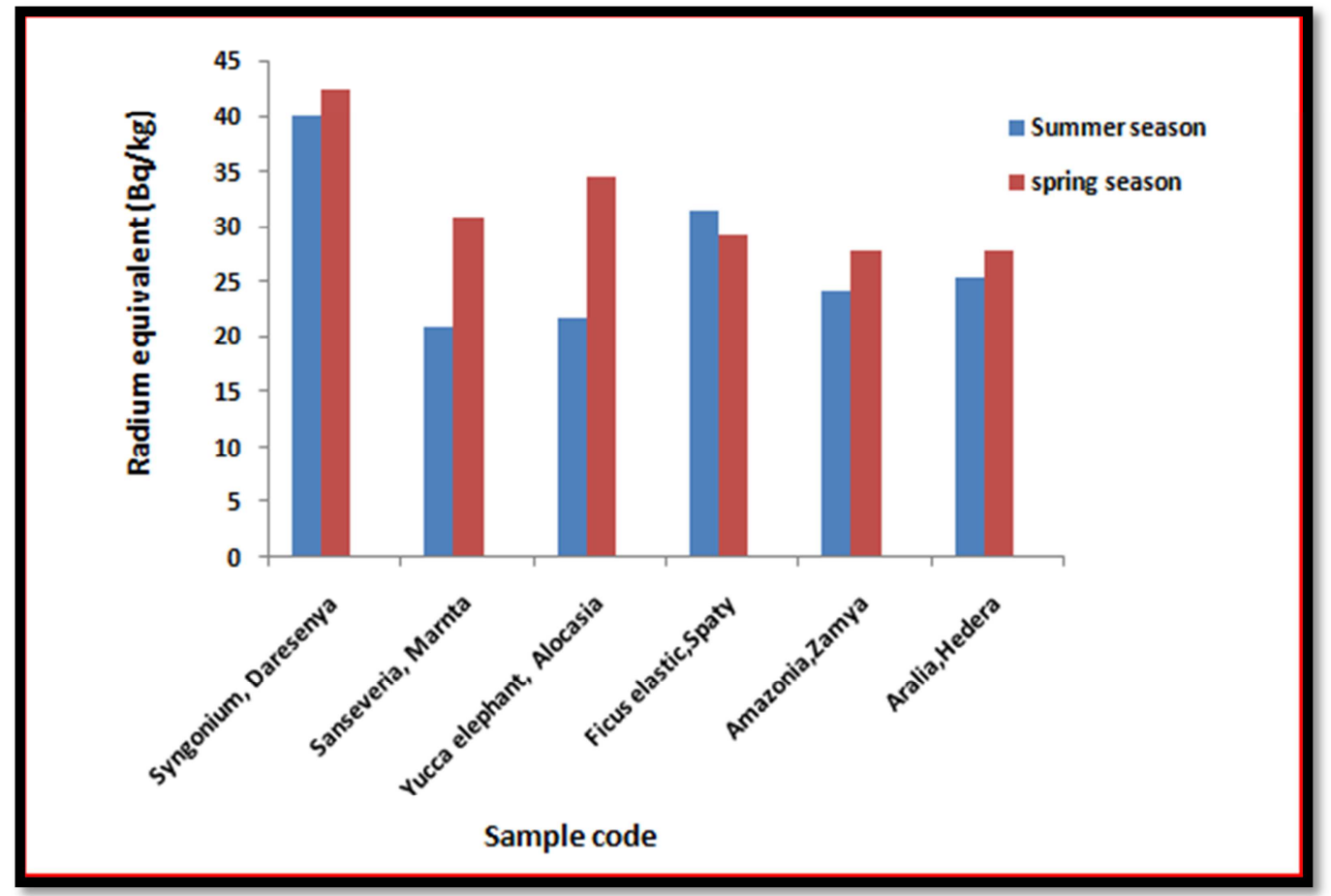

Figure 4. Radium equivalent of two seasons.

The mean external hazard index, gamma index and alpha index of the plants in spring season were $0.09 \pm 0.008$, $0.11 \pm 0.006$, and $0.05 \pm 0.006$ they were slightly higher than the mean values of the plants at summer season were $0.07 \pm 0.007$, $08 \pm 0.01$, and $0.02 \pm 0.004$. The block diagram of Hin, I $\gamma$ and $\mathrm{I} \alpha$ of two group of silhouette plants is shown in figure 5 . 


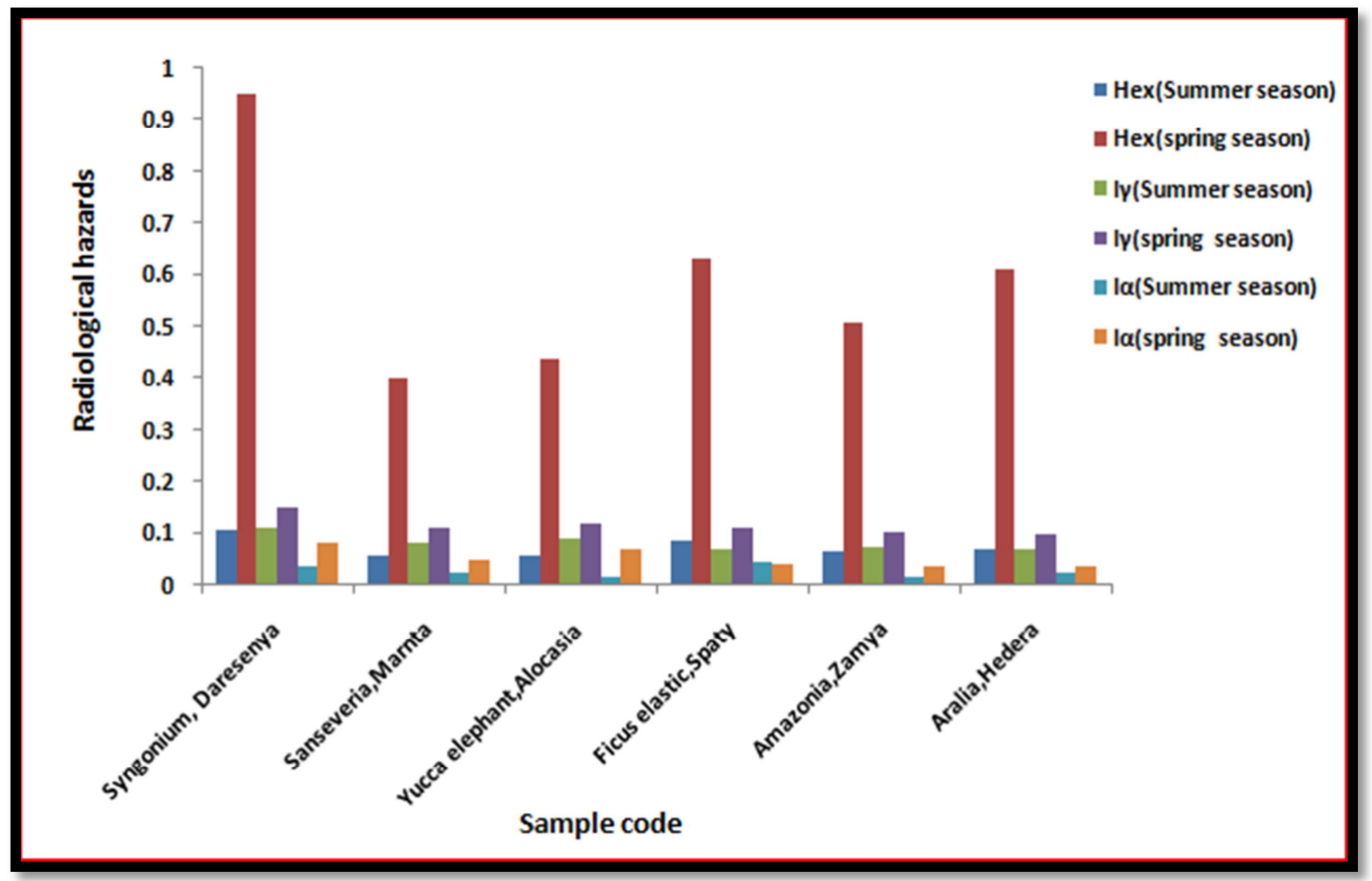

Figure 5. External hazard index, gamma index, and alpha index of two seasons.

The mean absorbed gamma dose rate of the first group plants $15.3 \pm 1 \mathrm{nGy} /$ his higher than the mean absorbed dose rate of the second group $13.2 \pm 1.3 \mathrm{nGy} / \mathrm{h}$. as shown in figure 6 .

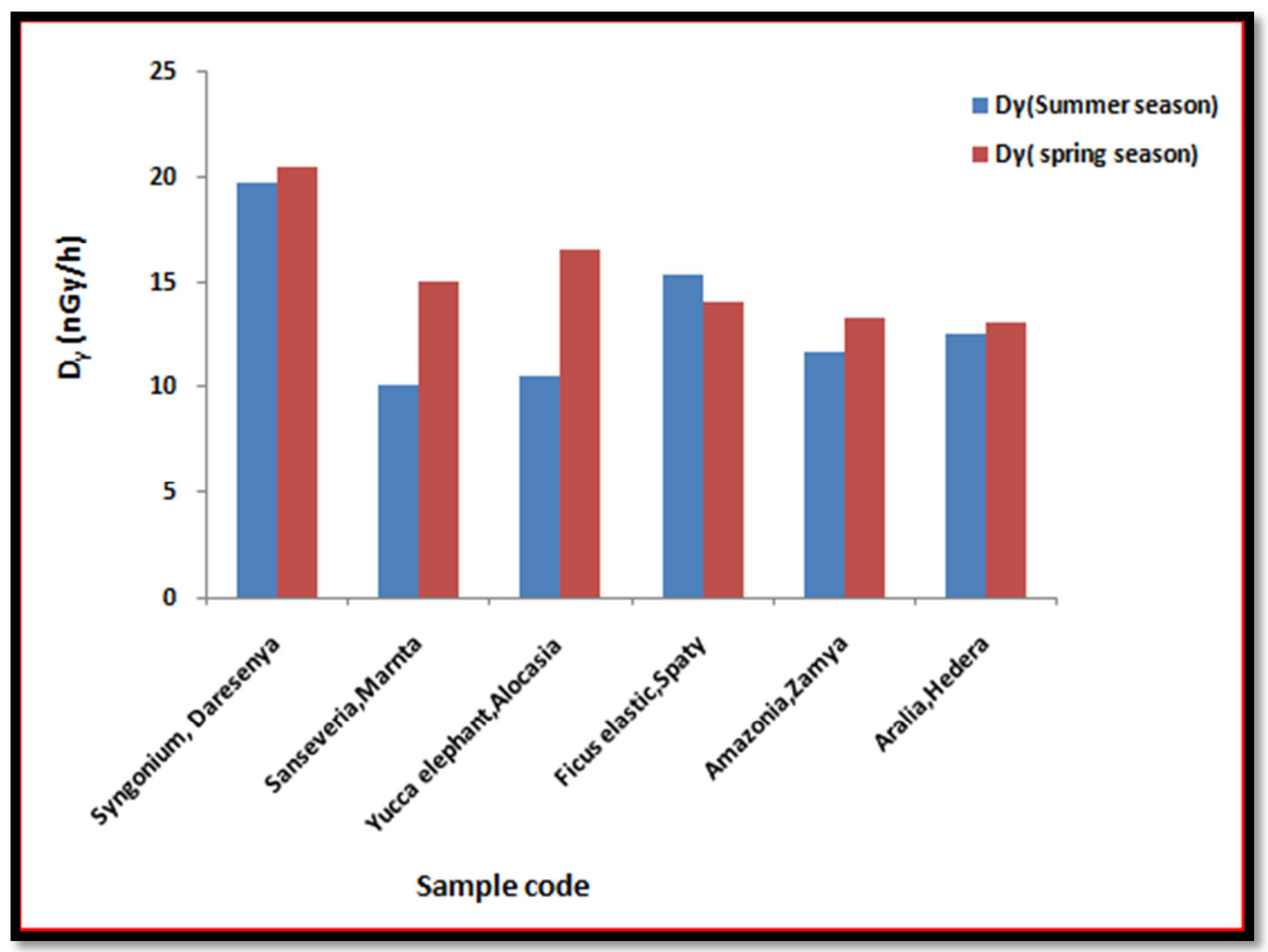

Figure 6. Absorbed gamma dose rate of two seasons.

The mean annual effective dose rate, and the annual gonadal dose equivalent at spring which were $0.07 \pm 0.002 \mathrm{mSv} / \mathrm{y}$, and $0.1 \pm 0.006 \mathrm{mSv} /$ yare slightly higher than the mean values at summer $0.06 \pm 0.1 \mathrm{mSv} / \mathrm{y}, 0.09 \pm 0.009 \mathrm{mSv} / \mathrm{y}$. Figure 7 shows the block diagram of the annual effective dose rate and figure 8 annual gonadal dose equivalent plants. 


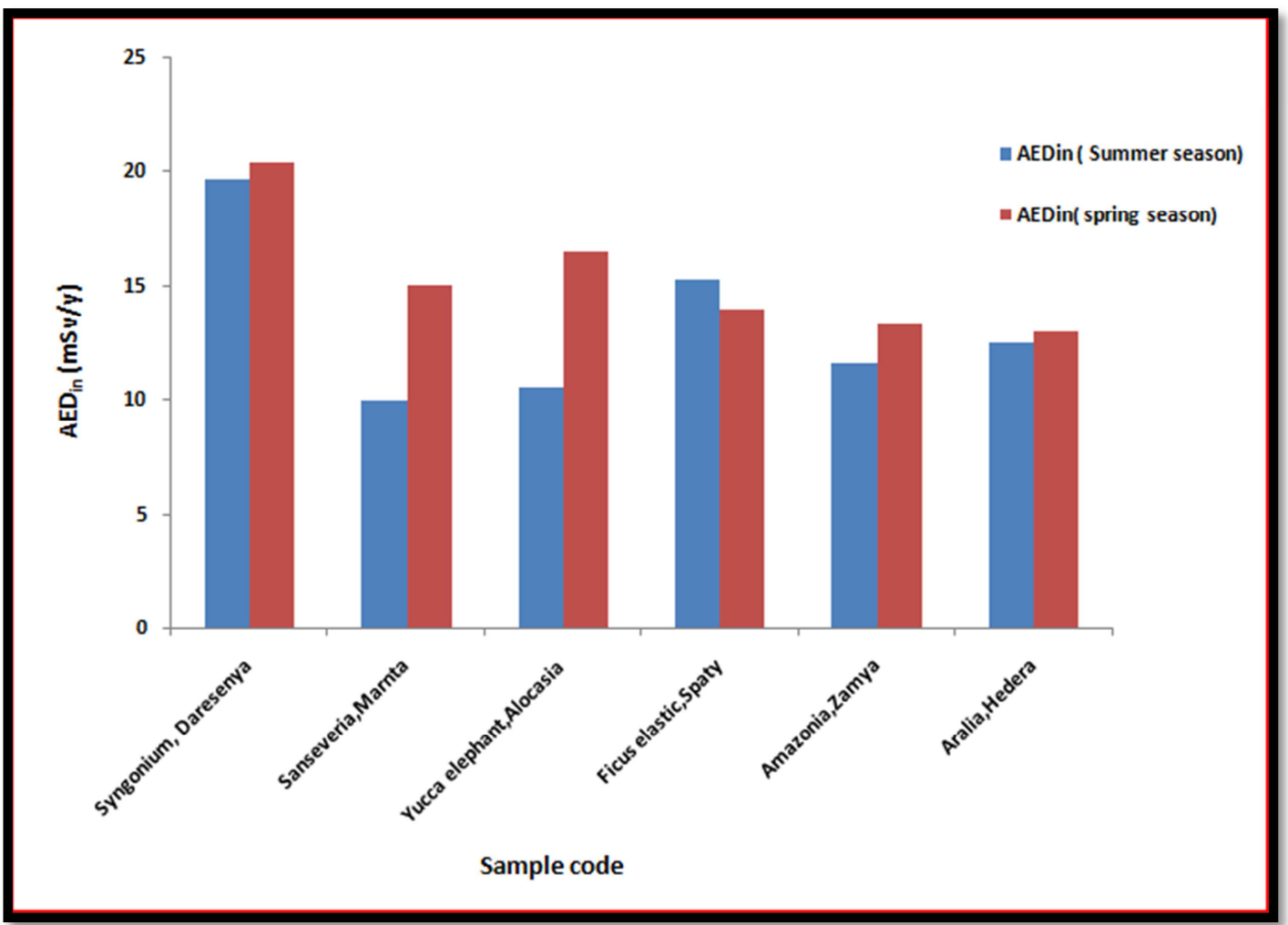

Figure 7. Annual effective dose rate of two seasons.

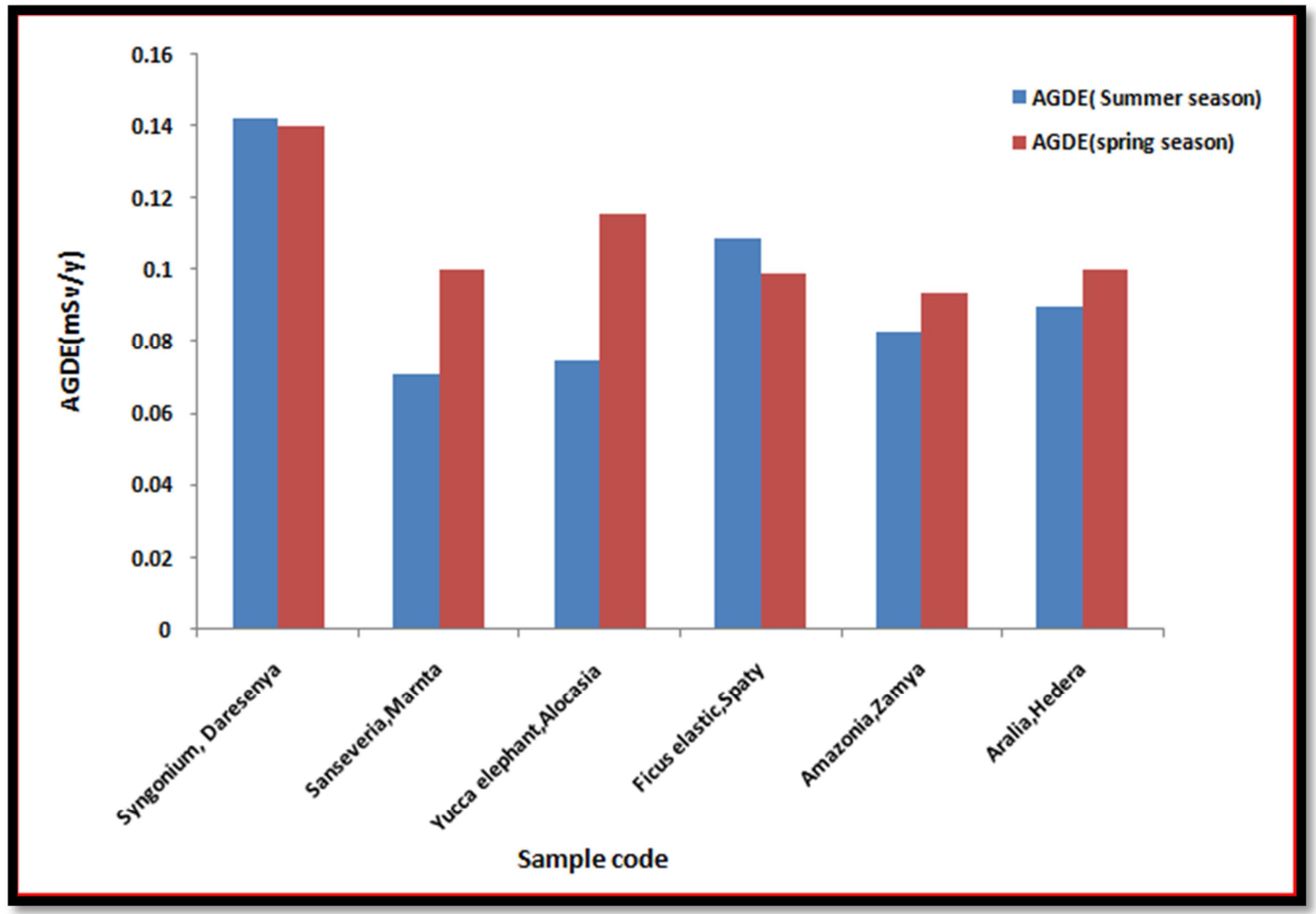

Figure 8. Annual gonadal dose equivalent of two seasons.

The mean excess lifetime cancer risk at spring $25 \pm 0.01$ is slightly higher than the mean excess lifetime cancer risk at summer $0.22 \pm 0.02$. The block diagram of the excess lifetime cancer risk of human of the two season plants is shown in figure 9 . 


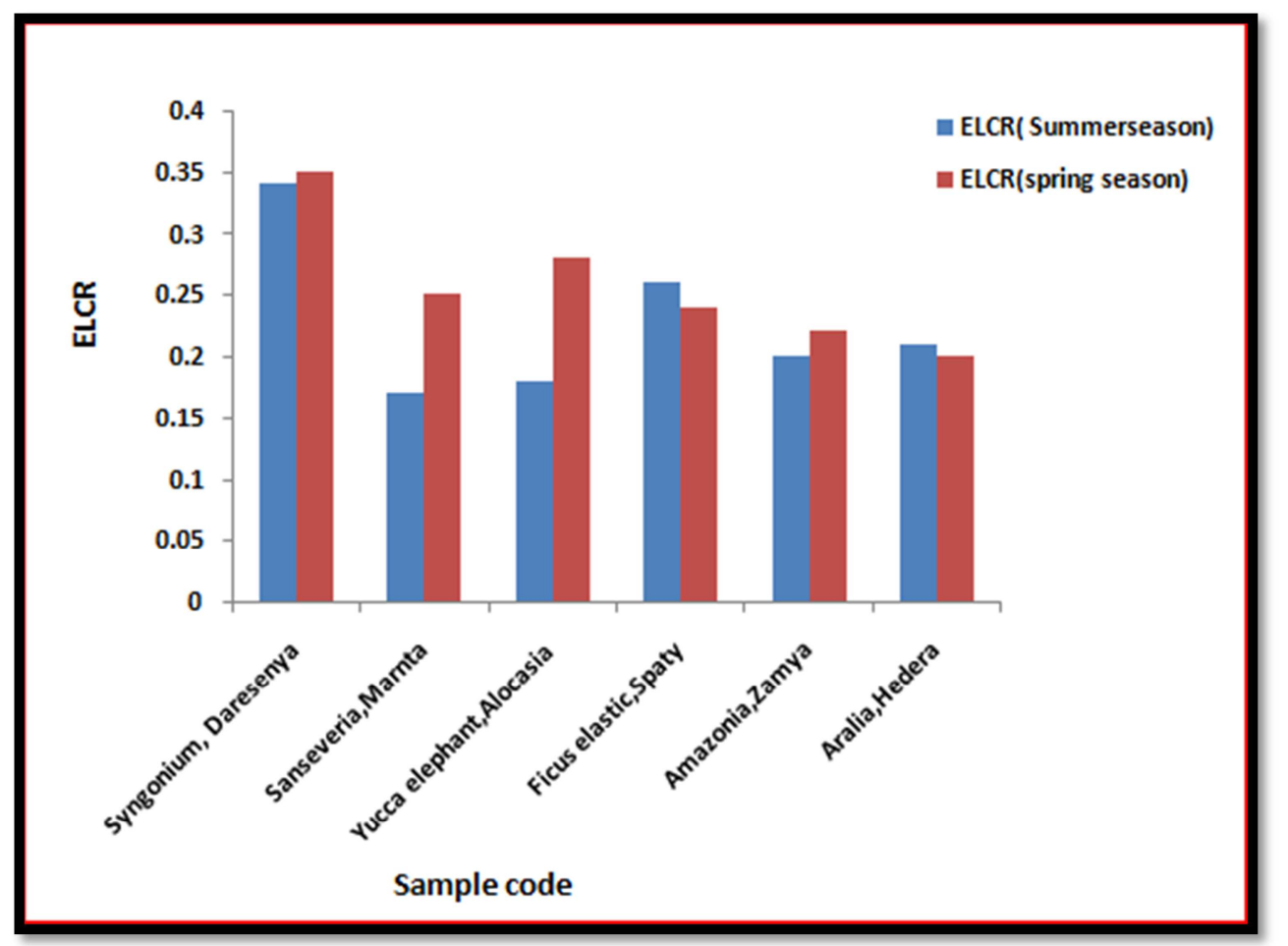

Figure 9. Excess lifetime cancer risk of human of two seasons.

\section{Conclusion}

A comparison between the radiation hazards of two groups of silhouette plants in two seasons were performed in this study, thus the mean specific activates of spring season plants are higher than the mean specific activates of the summer season plants, Daresenya plant has the highest specific activities, radium equivalent activities, external hazard index, gamma index, alpha index, gamma absorbed dose rate, annual effective dose, annual gonadal dose, and the Excess lifetime cancer risk for spring season plants, while Hedera plant has the lowest for summer season plants results of all these factors are below the recommended limits. This may be due to the, the temperature, moisture and barometric pressure (mbar), as well as the fertilizer used.

\section{Acknowledgements}

Authors would like to thank, applied radiation laboratory, Department of Physics, College of Science, Mustansiriyah University for their support and helping in finishing the manuscript.

\section{References}

[1] H. Taskin, M. Karavus, P. Ayb, A. Topuzoglu, S. Hidiroglu andG. Karahan., 2009. Radionuclide concentrations in soil and lifetime cancer risk due to gamma radioactivity in Kirklareli, Turkey Journal of Environmental Radioactivity. 100, 49-53.

[2] Adesijia, N. A., Ademolab, J. A., 2019. Soil-to-cassava plant transfer factor of natural radionuclides on a mining impacted soil in a tropical ecosystem of Nigeria. Journal Environmental Radioactivity. 1-4.

[3] Śmiełowska, M., Marć, M., Zabiegała, B., 2017. Indoor air quality in public utility environments-a review. Environmental Science and Pollution Research. Feb; 24. 12, 11166-11176.

[4] Appleton D., 2005. Radon In Air and Water, Essentials of Medical Geology. Editor: Olle Selinus, 227-63.

[5] Carvalho, F. P., Oliveira, J. M., Lopea, I., Batista, A., 2007. Radionuclides from past uranium mining in rivers of Portugal. J. Environ. Radioact. 98, 298-314.

[6] Alharbi, A., El-Taber, A., 2013. A study of the transfer factor of radionuclides from soil to plant. Life Sci. Journal. 2, 532539 .

[7] Kabata-Pendias, A., Pendias, H., 2000. Trace Elements in Soil and Plants, third ed. CRC Press, Boca Raton.

[8] Shtangeeva, I., 2010. Uptake of uranium and thorium by native and cultivated plants. Journal of Environmental Radioactivity. 101, 458-463.

[9] Adewumi, A, A., 2011. Assessment of norm-containing food crops/stuffs in OML 58 and OML 61 within the Niger delta region of Nigeria, Proceedings of the 1st international technology, education and environment conference, African society for scientific research [ASSR], 594-603.

[10] UNSCEAR., 2000. United Nations Scientific Committee on the Effect ofAtomic Radiation, Report to the General Assembly. Annex B: Exposures forNatural Radiation Sources, New York.

[11] Gruber, V., Maringer, F, J, Landstetter, C., 2009. Radon and other natural radionuclides in drinking water in Austria: measurement and assessment. Applied radiation and isotopes, No. 67. 5, 913-917. 
[12] Khan, H. M., Zia, M. A., Atta, M. A., Sail, M., 1997. Radioactivity in some dry milk powder and vegetables samples, Journal of Nuclear Science, 34, 209-214.

[13] Gaffer, S., Ferdous, M. J., Begum, A., Ullah, S. M., 2014. Transfer of natural radionuclides from soil to plants in North Western parts of Dhaka. Malaysian Journal of Soil Science 18, 61-74.

[14] Kaleel, M., Thabayneh, P., Mohammed, M, J., 2013. Radioactivity levels in plant samples in Tulkarem district, Palestine and its impact on the human health. Radiation Protection Dosimetry. 153. 4, 467-74.

[15] Sabine, Ehlken., Gerald, Kirchner., 2002. Environmental processes affecting plant root uptake of radioactive trace elements and variability of transfer factor data: a review. Journal of Environmental Radioactivity. 58, 97-112.

[16] Kadhim N. F. 2009. Studying the Natural Radioactivity in Some Tobacco Cigarettes Imported to Iraq from Unknown Origins, Jordan Medical Journal June. 43 (2): 83.

[17] KadhimN. F., Ridha A. A., 2019. Radiation hazards of the moassel consumed in Baghdad/Iraq using NaI (Tl) gamma spectroscopy, International Journal of Environmental Science and Technology. https://doi.org/10.1007/s13762-019-02373-9

[18] Kadhim N. F., Omeran A. M., 2019. Measurement the natural radioactivity of Sheep meat samples from Karbala governorate, an international scientific journal. 110-118.

[19] Jibiri, N, N., Farai, I. P., Alausa, S. K., 2007. Estimation of annual effective dose due to natural radioactive elements in ingestion of foodstuffs in the tin mining area of Jos-Plateau, Nigeria. Jounral. Environ. Radioact. 31-40.

[20] Al-Maqtary, K., Murshed, M., Bazohair, A., Al Zuhairy M., 2008. Determination of radio nuclides for some local foodstuffs in republic of Yemen, by using gamma rays spectral analysis technique. Abdhath AL-Yarmook: Basic Sci and Eng, $17,415-423$.

[21] Jose, A., Jorge, J., Cleomacio, M., Sueldo, V., Romilton, S., 2005. Analysis of the 40K Levels in Soil using Gamma Spectrometry. Brazilian Archives of Biology and Technology Journal. 221-228.
[22] Abid-Al Ammer, H., Kadhim, N, F., Karim, M, S., Ridha, A, A., 2017. Hazard Indices and Age Group Parameters of Powder Milk Consumed in Iraq. Higher Education Research 2: $117-122$.

[23] Al-Zahrani, J, H., 2017. Estimation of natural radioactivity in local and imported polished granite used as building materials in Saudi Arabia, Journal of Radiation Research and Applied Sciences 10, 241-245.

[24] El-Aziza, N, A, Khatera A E M, Al-Sewaidanb H, A., 2005. Natural radioactivity contents in tobacco. International Congress Series 1276. 407-408.

[25] Kafala, S. I., Macmahon, T. D., 2007. Comparison of neutron activation analysis methods Radiation physics and chemistry, 71, 507-516.

[26] Stoulos, S., Manolopoulou, M., Papastefanou, C., 2003. Assessment of Natural Radiation Exposure and Radon Exhalation from Building Materials in Greece. Journal of Environ. Radioactivity. 69, 225-240.

[27] Mahur, A, K., Kumer, R., Sonkawade, R, G., Sengupta, D., Prasad R., 2005.

[28] Estokova, A., Palascakova, L., 2013. Study of natural radioactivity of Slovack cements, Chemical Engineering Transactions. 32, 1675-1680.

[29] Chngizi, V., Shfiei E, Zareh, M, R., 2013. Measurement of 226Ra, 232Th, 137Cs40K, and activities of Wheat and Corn Products in Ilam Province - Iran and Resultant AnnualIngestion Radiation Dose, Iranian Journal Publ Health, 42, 903-914.

[30] ICRP, 1990. Recommendations of the International Commission on Radiological Protection, vol. 21 No. 1-3, publication 60 .

[31] ICRP, Publication 119, 2012. Compendium of dose coefficient based on ICRP Publication 60, 42, 4. 